\title{
The Mechanics of Machining Ultrafine-Grained Ti-6Al-4Mo Alloy Processed Severe Plastic Deformation
}

\begin{abstract}
Anastasiya Symonova ${ }^{1}$, Enrico Filippi ${ }^{2}$, Ján $\mathrm{Kmec}^{3}$, Ján Majerník ${ }^{3}$, Monika Karkova ${ }^{3}$
${ }^{1}$ Department of Mechanical Engineering, Kremenchuk Mykhailo Ostrohradskyi National University. Pershotravheva 20, 39600 Kremenchuk. Ukraine. E-mail: Nsymonova@gmail.com

${ }^{2}$ Department of Machine Design and Production Engineering, University of Mons. Place du Parc 20, B-7000 Mons. Belgium. E-mail: enrico.filippi@umons.ac.be

${ }^{3}$ Department of Mechanical Engineering, The Institute of Technology and Business in Ceske Budejovice. Okruzni 10, 37001 Ceske Budejovice. Czech Republic. E-mail: karkova@mail.vstecb.cz
\end{abstract}

The physics features of the cutting process of ultrafine-grained metals produced by the method of severe plastic deformation are considered. The aim of the research was to evaluate, whether the grain size of titanium alloy has an influence on the characterization of chips, the cutting force components, the surface roughness and the microhardness in the cutting process. The experimental data of the machineability of titanium alloy Ti-6Al-4Mo with sub microcrystalline structure are presented in the paper. The features of the chip formation, the changes of the chip ratio and the components of the cutting force are examined. The main characteristics of the cutting mechanics are calculated and based on the experimental values. Also the experimental values of the surface finish roughness and microhardness are shown. It is established, that the change in the structure of the metal has an ambiguous effect on machineability by cutting. Further investigation of the machineability of metals with a submicrocrystalline structure will allow to choose the efficient mechanical treatment.

Keywords: Ultrafine-grained, Titanium alloy, Machineability, Severe plastic deformtion

\section{Acknowledgement}

The authors would like to thank the Ukraine Ministry of Education and Science (project no. 38ДФ/(17-19)ТМu) for supporting this reseach.

\section{References}

[1] VALIEV, R.Z., ESTRIN, Y., HORITA, Z., LANGDON, T.G., ZEHETBAUER, M.J. ET AL. (2006). Producing bulk ultrafine-grained materials by severe plastic deformation. In: The Journal of The Minerals, Metals \& Materials Society, Vol. 58 (4), pp. 33 - 39. Springer. Germany.

[2] GORBATYUK, S.M., SHAPOVAL, A.A., MOS'PAN, D.V., DRAGOBETSKII, V.V. (2016). Production of periodic bars by vibrational drawing. In: Steel in Translation, Vol. 46, No. 7, pp. 474-478. Springer. Germany.

[3] VALIEV, R.Z., LANGDON, T.G. (2006). Principles of equal-channel angular pressing as a processing tool for grain refinement. In: Progress in Materials Science, Vol. 51 (7), pp. 881 - 981. Elsevier. USA.

[4] DONACHIE, MJ. JR. (2000). Titanium. A technical guide, second edition, chapter 4 machining, pp. 41 - 73. Ohio: ASM International.

[5] SYMONOVA, A.A., VEREZUB, O.N., SYCHEVA, A.A., VEREZUB, N.V., HAVIN, V.L., KAPTAY, G. (2012). Surface grain coarsening and surface during machining of ultra-grained titanium. In: Journal of Mining and Metallurgy. Sec. B, Vol. 48, pp. 378 - 389. University of Belgrade. Serbia.

[6] HABRAT, W., MOTYKA, M., TOPOLSKI, K., SIENIAWSKI, J. (2016). Evaluation of the cutting force components and the surface roughness in the milling process of micro- and nanocrystalline titanium. In: Archives of Metallurgy and Materials, Vol. 61, No. 3, pp. 1379 - 1384. DE GRUYTER OPEN. Warsaw.

[7] LAPOVOK, R., MOLOTNIKOV, A., Levin, Y., BANDARANAYAKE, A., ESTRIN, Y. (2012). Machining of coarse grained and ultra fine grained titanium. In: Journal of Materials Science, Vol. 47, pp. 4589 - 4594. Springer. Germany.

[8] SYMONOVA, A., DUCOBU, F., WEISS, V. (2016). The mechanics of machining ultrafine-grained Grade 2 Ti processed severe plastic deformation. In: Manufacturing Technology, Vol. 16, No. 3, pp. 627 - 633. ISSN 12132489. 
[9] SALISHCHEV, G.A., VALIAKHMETOV, R.O., GALEEV, R.M. (1993). Formation of submicrocrystalline structure in the titanium alloys BT8 and influence on mechanical properties. In: Journal of Materials Science, Vol. 28, pp. 2898 - 2902. Springer. Germany.

[10] ISO3685-1977(E). Tool-life testing with single-point turning tools. This standard has been revised by: ISO 3685:1993.9

[11] ZOREV, N.N. (1966). Metal Cutting Mechanics, pp. 65 - 108. Oxford: Pergamon Press.

[12] BACH, P., POLÁČEK, M., CHVOJKA, P., DROBÍLEK, J. (2014). Dynamic Forces in Unstable Cutting during Turning Operation. In: Manufacturing Technology, Vol. 14, No. 1, pp. 3-8. ISSN 1213-2489.

[13] CEPOVA, L., SOKOVA, D., MALOTOVA, S., Gapinski, B., CEP, R. (2016). Evaluation of Cutting Forces and Surface Roughness after Machining of Selected Materials. In: Manufacturing Technology, Vol. 16, No. 1, pp. 4548. ISSN 1213-2489.

[14] SHAW, M.C. (2005). Metal Cutting Principles, pp. 183 - 235. New York: Oxford Uni Press.

[15] ALTINTAS, YU. (2000). Manufacturing Automation: Metal Cutting Mechanics, Machin Tool Vibrations and CNC Design, pp. 34 - 75. Cambridge: Cambridge University Press.

[16] OXLEY, P. (1989). Mechanics of machining. An analytical approach to assessing machinability pp. 96 - 129. New York: Ellis Horwood Ltd.

[17] EZUGWU, E.O., WANG, Z.M. (1997) Titanium alloys and their machinability. In: Journal of Materials Processing Technology, Vol. 68, pp. 262 - 274. Elsevier. USA.

[18] KOMANDURI, R. (1982). Some clarifications on the mechanics of chip formation when machining titanium alloys. In: Wear, Vol. 76, pp. 15 - 34. Elsevier. USA.

[19] SUTTER, G., LIST, G. (2013). Very high speed cutting of Ti-6Al-4V titanium alloy-change in morphology and mechanism of chip formation. In: International Journal of Machine Tools and Manufacture, Vol. 66, pp. 37 - 43. Elsevier. USA.

[20] STOLYAROV, V.V., SHUSTER, L.SH., MIGRANOV, M.SH., VALIEV, R.Z., ZHU, Y.T. (2004). Reduction of friction coefficient of ultrafine-grained CP titanium. In: Materials Science and Engineering, Vol. 371 (1 - 2), pp. 313 - 317. Elsevier. USA.

[21] SIEGEL, R.W., NASTASI, M., PARKIN, D.M., GLIETER, H. (1993). Mechanical properties of ultrafine grained materials. In: Proc. of NATO ASI, Vol. 233, pp. 509 - 512. Dordrecht - Boston - London: Kluwer Head. Publ. 